\title{
Assessing the impact of counseling HTLV-1 seropositive women on vertical transmission in the GIPH cohort study, Brazil
}

\author{
Mariana A de Souza ${ }^{1,2^{*}}$, Cláudia LF Horiguchi ${ }^{1,2}$, Gabriela S Freitas ${ }^{1,2}$, Rafael HC Bastos ${ }^{1,2}$, Débora B Reiss ${ }^{1,2}$, \\ Marina L Martins ${ }^{2}$, Maria Sueli N Lopes ${ }^{2}$, Anna Bárbara FC Proietti ${ }^{1,2}$
}

From 16th International Conference on Human Retroviruses: HTLV and Related Viruses

Montreal, Canada. 26-30 June 2013

HTLV-1 is endemic in Brazil and is associated with major illnesses (HAM/TSP, ATL and uveitis). Since the infection remains asymptomatic in the majority of cases and screening is only performed in blood banks, there is an ongoing vertical transmission that remains unnoticed by the public health system. Although recommended by Brazilian researchers of the field, the prenatal screening for HTLV-1 or 2 was not yet implemented throughout the country. We performed a cross-sectional analysis to verify the impact of counseling HTLV-1 seropositive women in childbearing age participating in the GIPH cohort. The counseling included recommendations of not breastfeeding, giving infant formula and preferably having the child delivered by cesarean section. Children born from HTLV-1 seropositive women were divided in two groups: (1) born before and (2) after the participation of mothers in the GIPH cohort ("GIPH babies"). We have identified 21 children born to HTLV-1 positive mothers who received no counseling and 18 "GIPH babies", born from mothers who received counseling. $3 / 21(14.3 \%)$ and $1 / 18(5.6 \%)$ of the children were found positive for HTLV-1. The numbers will be expanded with active search of the remaining children not yet tested $(\mathrm{n}=15)$. Although the numbers are still preliminary, they point to a trend of successful counseling and avoidance of transmission of the virus. These actions should be widespread in the country to avoid the silent transmission of the virus.

\section{Authors' details}

${ }^{1}$ Faculdade da Saúde e Ecologia Humana (FASEH), Vespasiano, Minas Gerais, Brazil. ${ }^{2}$ Interdisciplinar de Pesquisa em HTLV (GIPH), Belo Horizonte, Minas Gerais, Brazil.

${ }^{1}$ Faculdade da Saúde e Ecologia Humana (FASEH), Vespasiano, Minas Gerais, Brazil

Full list of author information is available at the end of the article
Published: 7 January 2014

doi:10.1186/1742-4690-11-S1-P52

Cite this article as: de Souza et al:. Assessing the impact of counseling HTLV-1 seropositive women on vertical transmission in the GIPH cohort study, Brazil. Retrovirology 2014 11(Suppl 1):P52.
Submit your next manuscript to BioMed Central and take full advantage of:

- Convenient online submission

- Thorough peer review

- No space constraints or color figure charges

- Immediate publication on acceptance

- Inclusion in PubMed, CAS, Scopus and Google Scholar

- Research which is freely available for redistribution

Submit your manuscript at www.biomedcentral.com/submit
() Biomed Central 